Fixed Point Theory, 22(2021), No. 1, 359-376

DOI: $10.24193 /$ fpt-ro.2021.1.25

http://www.math.ubbcluj.ro/ nodeacj/sfptcj.html

\title{
A NOVEL HYBRID METHOD FOR EQUILIBRIUM PROBLEM AND A COUNTABLE FAMILY OF GENERALIZED NONEXPANSIVE-TYPE MAPS WITH APPLICATIONS
}

\author{
MARKJOE OLUNNA UBA*, EMMANUEL EZZAKA OTUBO**,+, \\ MARIA AMARAKRISTI ONYIDO* $*++$ \\ *University of Nigeria, Nsukka \\ E-mail: markjoe.uba@unn.edu.ng \\ **A Auburn University, Abuja \\ +Ebonyi State University, Abakaliki \\ E-mail: eeo0010@auburn.edu \\ ${ }^{++}$Auburn University, USA \\ E-mail: mao0021@auburn.edu
}

\begin{abstract}
Let $C$ be a nonempty closed and convex subset of a uniformly smooth and uniformly convex real Banach space $E$ with dual space $E^{*}$. A novel hybrid method for finding a solution of an equilibrium problem and a common element of fixed points for a family of a general class of nonlinear nonexpansive maps is constructed. The sequence of the method is proved to converge strongly to a common element of the family and a solution of the equilibrium problem. Finally, an application of our theorem complements, generalizes and extends some recent important results (Takahashi et al., Strong convergence theorems by hybrid methods for families of nonexpansive mappings in Hilbert spaces, J. Math. Anal. Appl., 341 (2008), 276-286., Nakajo and Takahashi, Strong convergence theorems for nonexpansive mappings and nonexpansive semi-groups, J. Math. Anal. Appl. vol. 279 (2003), 372-379., Qin and Su, Strong convergence of monotone hybrid method for fixed point iteration process, J. Syst. Sci. and Complexity 21 (2008) 474-482., Klin-eam et al., Hybrid method for the equilibrium problem and a family of generalized nonexpansive mappings in Banach spaces, J. Nonlinear Sci. Appl. 9 (2016), 4963-4975).
\end{abstract}

Key Words and Phrases: Equilibrium problem, $J_{*}$ fixed points, strong convergence.

2020 Mathematics Subject Classification: 47H09, 47H05, 47J25, 47J05, 47H10.

Acknowledgments. The authors are thankful to the anonymous referees for their valuable and esteemed suggestions which have helped to improve the final version of the manuscript.

\section{REFERENCES}

[1] R.P. Agarwal, M. Meehan, D. O'Regan, Fixed Point Theory and Applications, vol. 141, Cambridge University Press, 2001. 
[2] Y. Alber, Metric and generalized projection operators in Banach spaces: properties and applications, in: Theory and Applications of Nonlininear Operators of Accretive and Monotone Type (A.G. Kartsatos, Ed.), Marcel Dekker, New York, 1996, 15-50.

[3] Y. Alber, S. Guerre-Delabriere, On the projection methods for fixed point problems, Analysis (Munich), 21(2001), no. 1, 17-39.

[4] Y. Alber, I. Ryazantseva, Nonlinear Ill Posed Problems of Monotone Type, Springer, London, UK, 2006.

[5] A. Aleyner, S. Reich, Block-iterative algorithms for solving convex feasibility problems in Hilbert and in Banach spaces, J. Math. Anal. Appl., 343(2008), no. 1, 427-435.

[6] P. Benilan, M.G. Crandall, A. Pazy, Nonlinear evolution equations in Banach spaces (preprint), Besançon, 1994.

[7] V. Berinde, Iterative Approximation of Fixed Points, Lecture Notes in Mathematics, Springer, London, UK, 2007.

[8] E. Blum, W. Oettli, From optimization and variational inequalities to equilibrium problems, Math. Stud., 63(1994), 123-145.

[9] F.E. Browder, Nonlinear mappings of nonexpansive and accretive-type in Banach spaces, Bull. Amer. Math. Soc., 73(1967).

[10] F.E. Browder, Nonlinear equations of evolution and nonlinear accretive operators in Banach spaces, Bull. Amer. Math. Soc., 73(1967), 875-882.

[11] L.C. Ceng, A. Petruşel, J.C. Yao, Iterative approximation of fixed points for asymptotically strict pseudocontractive type mappings in the intermediate sense, Taiwanese J. Math., 15(2011), no. 2.

[12] Y. Censor, S. Reich, Iterations of paracontractions and firmly nonexpansive operators with applications to feasibility and optimization, Optimization, 37(1996), no. 4, 323-339.

[13] S. Chang, J.K. Kim, X.R. Wang, Modified block iterative algorithm for solving convex feasibility problems in Banach spaces, J. Ineq. Applications, vol. 2010, art. ID 869684, DOI: $10.1155 / 2010 / 869984$.

[14] C.E. Chidume, Geometric Properties of Banach Spaces and Nonlinear iterations, vol. 1965 of Lectures Notes in Mathematics, Springer, London, UK, 2009.

[15] C.E. Chidume, A.U. Bello, An iterative algorithm for approximating solutions of Hammerstein equations with monotone maps in Banach spaces, Applied Math. Computation, 313(2017), issue $\mathrm{C}, 408-417$.

[16] C.E. Chidume, K.O. Idu, Approximation of zeros of bounded maximal monotone maps, solutions of Hammerstein integral equations and convex minimization problems, Fixed Point Theory Appl., (2016), 2016:97 DOI 10.1186/s13663-016-0582-8.

[17] C.E. Chidume, M.O. Uba, M.I. Uzochukwu, E.E. Otubo, K.O. Idu, A strong convergence theorem for an iterative method for finding zeros of maximal monotone maps with applications to convex minimization and variational inequality problems, Proc. Edinburgh Math. Soc., 1-17. doi:10.1017/S0013091518000366.

[18] I. Cioranescu, Geometry of Banach Spaces, Duality Mappings and Nonlinear Problems, vol. 62, Kluwer Academic Publishers, 1990.

[19] P.L. Combettes, The convex feasibility problem in image recovery, in: Advances in Imaging and Electron Physics (P. Hawkes, Ed.), 95(1996), Academic Press, New York, NY, USA, 155-270.

[20] P.L. Combettes, S.A. Hirstoaga, Equilibrium programming in Hilbert spaces, J. Nonlinear Convex Anal., 6(2005), 117-136.

[21] K. Diemling, Nonlinear Functional Analysis, Springer-Verlag, 1985.

[22] S.D. Flam, A.S. Antipin, Equilibrium programming using proximal-link algorithms, Math. Program., 78(1997), 29-41.

[23] T. Ibaraki, W. Takahashi, A new projection and convergence theorems for the projections in Banach spaces, J. Approx. Theory, 149(2007), 1-14.

[24] H. Iiduka, W. Takahashi, Strong convergence studied by a hybrid type method for monotone operators in a Banach space, Nonlinear Anal., 68(2008), 3679-3688.

[25] S. Kamimura, W. Takahashi, Strong convergence of a proximal-type algorithm in a Banach space, SIAM J. Optim., 13(2002), no. 3, 938-945. 
[26] T. Kato, Nonlinear semigroups and evolution equations, J. Math. Soc. Japan, 19(1967), 508520.

[27] H. Khatibzadeh, G. Morosanu, Strong and weak solutions to second order differential inclusions governed by monotone operators, Set-Valued and Variational Anal., 22(2014), no. 2, 521-531.

[28] H. Khatibzadeh, A. Shokri, On the first and second-order strongly monotone dynamical systems and minimization problems, Optimization Methods and Software, 30(2015), no. 6, 1303-1309.

[29] M. Kikkawa, W. Takahashi, Approximating fixed points of nonexpansive mappings by the block iterative methods in Banach spaces, International Journal of Computational and Numerical Analysis and Applications, 5(2004), 1, 59-66.

[30] S. Kitahara, W. Takahashi, Image recovery by convex combination of sunny nonexpansive retractions, Topological Meth. Nonlinear Anal., 2(1993), no. 2, 333-342.

[31] C. Klin-eam, P. Kaskasem, S. Suantai, Hybrid method for the equilibrium problem and a family of generalized nonexpansive mappings in Banach spaces, J. Nonlinear Sci. Appl., 9(2016), 49634975.

[32] F. Kohsaka, W. Takahashi, Generalized nonexpansive retractions and a proximal-type algorithm in Banach spaces, J. Nonlinear Convex Anal., 8(2007), 197-209.

[33] H.Y. Li, Y.F. Su, Strong convergence theorems by a new hybrid for equilibrium problems and variational inequality problems, Nonlinear Anal., 72(2009), no.2, 847-855.

[34] B. Liu, Fixed point of strong duality pseudocontractive mappings and applications, Abstract Applied Anal., Vol 2012, art. ID 623625, 7 pages, doi:10.1155/2012/623625.

[35] A. Moudafi, M. Théra, Proximal and Dynamical Approaches to Equilibrium Problems, Lecture Note in Economics and Mathematical Systems, Vol. 477, M. Théra and R. Tichatschke, eds., Springer-Verlag, New York, 1999, 187-201.

[36] K. Nakajo, K. Shimoji, W. Takahashi, Strong convergence theorems to common fixed points of families of nonexpansive mappings in Banach spaces, J. Nonlinear Convex Anal., (2007), 11-34.

[37] K. Nakajo, W. Takahashi, Strong convergence theorems for nonexpansive mappings and nonexpansive semi-groups, J. Math. Anal. Appl., 279(2003), 372-379.

[38] J.G. ǑHara, P. Pillay, H.K. Xu, Iterative approaches to finding nearest common fixed points of nonexpansive maps in Hilbert spaces, Nonlinear Anal., 54(2003), 1417-1426.

[39] M.A. Onyido, M.O. Uba, M.I. Uzochukwu, P.U. Nwokoro, E.E. Otubo, A theorem for zeros of maximal monotone and bounded maps in certain Banach spaces, J. Advances in Mathematics and Computer Science, 19(2016), no. 1, 1-12.

[40] D. Pascali, S. Sburian, Nonlinear Mappings of Monotone Type, Editura Academiei Bucureşti, Romania, 1978.

[41] X. Qin, Y.J. Cho, S.M. Kang, Convergence theorems of common elements for equilibrium problems and fixed point problems in Banach spaces, J. Computational and Applied Math., 225(2009), no. 1, 20-30.

[42] X. Qin, Y. Su, Strong convergence of monotone hybrid method for fixed point iteration process, J. Syst. Sci. and Complexity, 21(2008), 474-482.

[43] S. Reich, Strong convergence theorems for resolvents of accretive operators in Banach spaces, J. Math. Analysis Appl., 75(1980), no. 1, 287-292.

[44] D.R. Sahu, H.K. Xu, J.C. Yao, Asymptotically strict pseudocontractive mappings in the intermediate sense, Nonlinear Anal., 70(2009), no. 10, 3502-3511.

[45] R.E. Showalter, Monotone Operators in Banach Spaces and Nonlinear Partial Differential Equations, Mathematical Surveys and Monographs, 49(1997), AMS.

[46] S. Takahashi, W. Takahashi, Viscosity approximation methods for equilibrium problems and fixed point problems in Hilbert spaces, J. Math. Anal. Appl., 331(2007), 506-515.

[47] W. Takahashi, Y. Takeuchi, R. Kubota, Strong convergence theorems by hybrid methods for families of nonexpansive mappings in Hilbert spaces, J. Math. Anal. Appl., 341(2008), 276-286.

[48] W. Takahashi, K. Zembayashi, A strong convergence theorem for the equilibrium problem with a bifunction defined on the dual space of a Banach space, Fixed Point Theory and its Applications, Yokohama Publ., Yokohama, (2008), 197-209.

[49] W. Takahashi, K. Zembayashi, Strong and weak convergence theorems for equilibrium problems and relative nonexpansive mappings in Banach spaces, Nonlinear Anal., 70(2009), no. 1, 45-57. 
[50] M.O. Uba, A.U. Bello, C.E. Chidume, Approximation of solutions of Hammerstein equations with bounded monotone maps in Lebesgue spaces, Pan American Math. J., 29(2019), no. 3, 34-53.

[51] M.O. Uba, M.I. Izuchukwu, M.A. Onyido, Algorithm for approximating solutions of Hammerstein integral equations with maximal monotone operators, Indian J. Pure Appl. Math. 48(2017), 391.

[52] M.O. Uba, M.A. Onyido, An algorithm for solutions of Hammerstein integral equations with maximal monotone operators in classical Banach spaces, J. Advances in Mathematics and Computer Science, 19(2016), no. 1, 1-12.

[53] M.O. Uba, M.A. Onyido, P.U. Nwokoro, Iterative approximation of solutions of Hammerstein integral equations with maximal monotone operators in Banach spaces, J. Advances in Mathematics and Computer Science, 19(2016), no. 2, 1-15.

[54] V. Volpert, Elliptic Partial Differential Equations, vol. 2: Reaction-Diffusion Equations, Vol. 104 of Monographs in Mathematics, Springer, 2014.

[55] K. Wattanawitoon, P. Kumam, Strong convergence theorems by a new hybrid projection algorithm for fixed point problems and equilibrium problems of two relatively quasi-nonexpansive mappings, Nonlinear Analysis: Hybrid Systems, 3(2009), no. 1, 11-20.

[56] K. William, N. Shahzad, Fixed Point Theory in Distance Spaces, Springer Verlag, 2014.

[57] H.K. Xu, Inequalities in Banach spaces with applications, Nonlinear Anal., 16(1991), no. 12, 1127-1138.

[58] H. Zegeye, Strong convergence theorems for maximal monotone mappings in Banach spaces, J. Math. Anal. Appl., 343(2008), 663-671.

[59] H. Zegeye, E.U. Ofoedu, N. Shahzad, Convergence theorems for equilibrium problem, variational inequality problem and countably infinite relatively quasi-nonexpansive mappings, Appl. Math. Comput., 216(2010), 3439-3449.

[60] H. Zegeye, N. Shahzad, Strong convergence for monotone mappings and relatively weak nonexpansive mappings, Nonlinear Anal., 70(2009), 2707-2716.

[61] H. Zegeye, N. Shahzad, Strong convergence theorems for a solution of finite families of equilibrium and variational inequality problems, Optimization, 63(2014), no. 2, 207-223.

[62] E. Zeidler, Nonlinear Functional Analysis and its Applications, Part II: Monotone Operators, Springer-Verlag, Berlin, 1985.

[63] H. Zhou, G. Gao, B. Tan, Convergence theorem of a modified hybrid algorithm for a family of quasi- $\phi$-asymptotically nonexpansive mappings, J. Applied Mathematics and Computing, 32(2010), no. 2, 453-464.

Received: October 18, 2018; Accepted: December 16, 2019. 